\title{
Methodological aspects of the construction of the innovative model of a sustainable development of cities in the imperatives of contemporaty policy of the Organization of the United Nations: essence and modernization
}

\author{
Irina V. Bogomolova \\ Volgograd State Technical University, \\ Chair of Management and Development of \\ the Municipal Economy and Construction, \\ Professor \\ Volgograd, Russia \\ bogirvik@gmail.com
}

\author{
Vitaly S. Borovik \\ Scientific and Technical Advisory Council \\ at the Head of the \\ Administration of Volgograd \\ Chair \\ Volgograd, Russia \\ borovikv@mail.ru
}

\author{
Lyudmila S. Mashentsova \\ Volgograd State Technical University, \\ Chair of Management and Development of \\ Municipal Economy and Construction, \\ Postgraduate Student \\ Volgograd, Russia \\ m_luda09@mail.ru
}

\begin{abstract}
The problems of the provision of a sustainable development of cities and inhabited localities at the September Summit of 2015 held by the Organization of the United Nations are categorized as ones of the most important for the nearest years. In the article on the basis of the methodological research carried out by the authors a modernized model of the sustainable development of the cities is suggested. It includes not only the criteria suggested by the UN: inclusivity, safety, resilience, sustainability and also additional conditions for a sustainable development like competitiveness and potential. The authors discover the essence of the innovative model and proves the possibility of the achievement of the synergy effect under the condition of the simultaneous provision of all six constituents of a sustainable development. The consolidation of the efforts of authorities, local communities and of city people during the universal preparation of the papers of the strategic planning of the social and economic development of Russian territories will allow providing a qualified growth of the quality of life of the population by means of the use of the authors approach to the study of the essence of a stable development.
\end{abstract}

Keywords - sustainable urban development, inclusivity, safety, resilience, sustainability, competitiveness and viability of cities, methodology, innovative model of economic space

\section{INTRODUCTION}

The rapid growth of the globalization accompanied by the urbanization of practically of all the countries and continents determined the necessity of the analysis and the solution of the problems of the provision of a sustainable development of cities. The problems of the provision of a sustainable development during latest twenty years remain important enough and various attempts of an all sided research of the given notion were made. The subject of a sustainable development for the moment is becoming an interdisciplinary problem and occupies the minds of scientists of various specialties living in different countries and continents. The dynamic rates of the urbanization of development emphasize the scientific and practical importance of the suggestion of the notion of the sustainable city development [1].

In the beginning of XXI the century the main postulates of the sustainable city development were formulated which became by nature the program documents. The first document which was adopted in 2007 was the Leipzig Charter on Sustainable European Cities which contributed to the integration of the ideology of a sustainable development into the policy of the regional and local development. In the 
following year the Covenant of Mayors for Climate and Energy was adopted in which the necessity of the increase of the energy efficiency and the growth of use of the renewable energy sources in the cities participants of the Covenant were identified. In 2008 the promotional event "Green capital of Europe" encouraging the city contributing to an ecologically friendly and attractive city environment had a wide spread diffusion. A while later in 2013 the Reference Framework for European Sustainable Cities was developed which provided the promotion in the cities of the activity of the sustainable development on the basis of the principle of the equilibrium of the ecological, social and economic spheres. In 2015 the September Summit of the UN the new sustainable development goals (Make cities and human settlements inclusive, safe, resilient and sustainable) were adopted where a special attention was paid to an all round development of the cities and communities in the provision of their inclusivity, safety, resilience and sustainability.

\section{MATERIALS AND Methods (MODEL)}

Up to the present moment there has not been a common approach to the definition of a «sustainable city development» and the main attention by the scientists is paid to the development of countries and the regions. We suppose that the sustainable development of a city presents a city strategy focused on the provision of a progressive growth of the standard and quality of life of the population at a dynamic development of the ecological, social and economic systems of the city.

Earlier the scientists of the Volgograd scientific school suggested a formalized model of a competitive, sustainable and safe development of a region. The mentioned components were seen as necessary indices of the development of the economic systems and their unity was presented as a three dimensional model of coordinates. Depending on the remoteness of the indices of the threshold values the condition of the regional economy was determined in the following way: normal, crisis and critical one. And the more equal the values of the indices are the higher the level of the development of a region is [2].

The advantage of this methodology is the opportunity of using it for the analysis of administrative and territorial systems of various levels. We think that the given approach can be used for the development of the essence and the assessment of the basic conditions of the provision of a sustainable development of the cities.

When analyzing a sustainable development of the cities from the point of view of their external support the goal of the search of the external forces contributing to it is found. The main conditions for the provision of a sustainable development of the cities are marked by goal №11 suggested in the Summit of the UN (September 2015). If we develop the ideas mentioned in the papers of the UN and also if we take into account the complexity and the variety of the topic of the sustainable development of the cities we believe that in the modern world the main conditions of the provision of a sustainable development should become the competitive ability (competitiveness), sustainability, safety, resilience, inclusivity and perspectives (potential) of the cities. Graphically the conditions of the sustainable development can be presented in the shape of a flower where every petal presents one of the conditions for the achievement of a sustainable development (Figure 1).

Every of the mentioned conditions show that a progressive movement in the direction of sustainable development and the integral influence at the expense of the achievement of an additional synergetic effect exceeds in our opinion a simple sum of the summands [3]. If we take that the force of the impact of every condition is equal to one, so

$$
\mathrm{C}+\mathrm{S}+\mathrm{Sf}+\mathrm{R}+\mathrm{I}+\mathrm{P}>6(2)
$$

The provision of all six conditions at a time in the process of the realization of the strategy is capable of providing of a synergy effect and a moral satisfaction of the population of the opportunity to live in the given city (community).

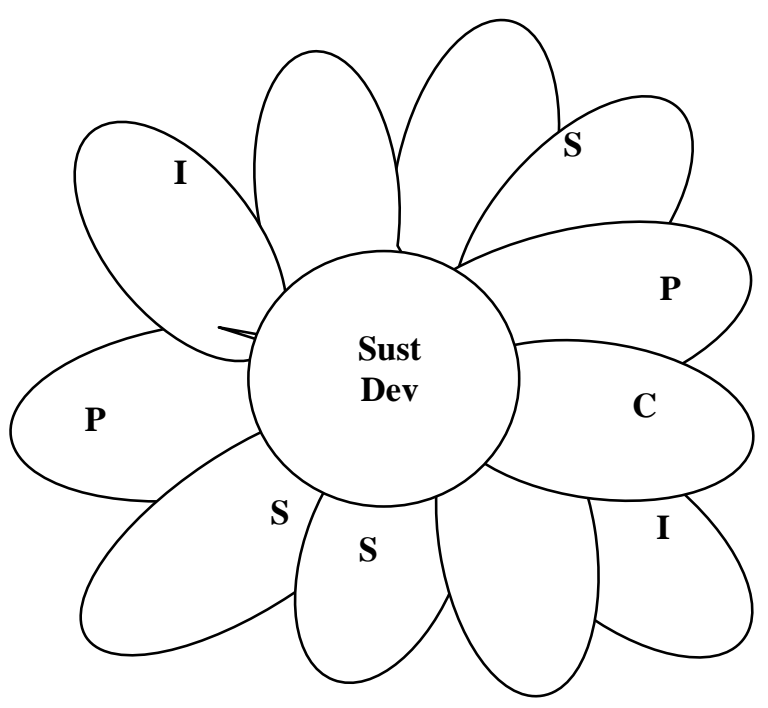

Figure 1. Conceptual model of the conditions of a stable development of large cities

In general terms the sustainable development of large cities can be presented in the form of a function:

The sustainable development of large cities $=\mathrm{F}(\mathrm{C}, \mathrm{S}, \mathrm{Sf}$, R, I, P), (1), where

C-Competitiveness,

S - Sustainability,

Sf - Safety,

R - Resilience,

I - Inclusivity,

$\mathrm{P}-$ Perspectives (potential).

It can be confirmed that a sustainable development of cities presents an integrated process directed on the improvement of the conditions and the quality of life of city 
people. It has a balanced ecological, economic and social sphere by means of the achievement of their dynamic development taking place on the basis of a rational use of all the resource potential including the demographic, geographic, and town planning specificity of a territory. The peculiarity of the contemporary period of the development of the society, economy and the space is the necessity of the analysis of a stable development in a large sense responding to the conditions (criteria) of the competitiveness, sustainability, safety, resilience, inclusivity and perspectives (potential).

\section{RESULTS AND DISCUSSION}

The renovation of the economic space of any city is connected with a number of the interrelated and interdependent problems the solution of which is impossible without taking into account new social and economic tendencies, relationships and contradictions of the functioning of the modern Russian society, transformation of the social needs, clustering processes and reorientation of the strategies of the cities' development on the promotion of the territorial competition of the cities.

In the English scientific literature the term "inclusive" was used which is conserved by us in our paper. In the Russian translation of the UN papers the notion "openness" was used [4]. It is worth mentioning that both of these terms are close to each other and emphasize a positive impact on the degree of a sustainable city development. When analyzing the essence of the inclusivity it is necessary to notice four principles providing its inclusive development [5]. In the first turn the inclusivity formulates the problem of the democratization of the international relations by means of the provision of a rational location of the political, economic reforming of a global financial system.

The second principle of the inclusivity is the increase of the quality of life of the population at the expense of the modernization of the production, informational technologies and the implementation of the innovative projects. The newest technologies and comforts of home should not be destined only to the rich people of the world or only to some countries of the world.

The accessibility of a qualified education, development of human resources, and the creation of highly profitable and safe working places are expected to be country wide. Cities and first of all the large ones should use the modernization way and the model of the development of five "I"s: innovations, investment, infrastructure, institutes and human intellect. The given principle is correlated with the goal of sustainable development №4 implying the provision of an inclusive and fair education.

The third principle of the inclusivity is the policy in the sphere of the use of natural resources and climate which are the catalysts for the modernization of the production, increase of the energy efficiency and also the introduction of green technologies. In the goals of sustainable development the access to secure, cheap, accessible and sustainable transport systems, provision of the security on the roads by means of paying attention to women, children, handicapped people and elderly people are stipulated. The provision of a healthy way of living, provision of the places of an active recreation and physical training will contribute to a normalization of the psychological condition of the city people.

The fourth principle is the tolerance and the preparedness to integration changes. The inclusivity of the modern city implies the openness of a local community, comfort of life and doing business, tolerance to migrants from other ethnic and confessional groups. The openness to the surrounding world is characterized by the policy of the open relations including inter-municipal and twin town relations. The creation of a positive image of the city in the country and beyond is inevitably connected with the condition of the informational sphere, with the introduction of the information technologies in the education, medicine, social security, culture.

At the international level the experts of the ISO understand under the principle the inclusivity (openness) of the activity of the organs of the local administration which is considered as one of the factors influencing the development of the cities and communities. The use of the developed standard ISO 18091:2014 «System of quality management. The guidelines in the use of ISO 9001:2008 in local authorities» implies the expansion of the rights of the citizens what should lead to the confidence of the bodies of authorities; law enforcement by the local authorities; development of the interaction of political, social and technical structures at the local, national and international levels [6]. Consequently all the constituents of the model of the social and economic development are expected to correspond to the inclusivity (openness) principle.

Under the conditions of a quick growth of the city population due to migration the measures of the upbringing of a tolerant attitude to newcomers becomes important. For this the preventive measures (extremism controls, terrorism and tolerance education) are foreseen.

The mentioned sphere is correlated with the necessity of the provision of the safety which is considered to be a second condition of a sustainable development. The strategy of the sustainable development is inseparably connected with the conception of safety. The city comfortable for life and work is expected to provide its inhabitants with the economic and physical security.

The connection of the notions "sustainable development" and "safety" notice numerous scientists emphasizing the ecological constituent of the safety [7]. Another group of scientists suggested the factors of the mutual influence of the safety, inclusivity, competitiveness and sustainable development $[8,9,10]$. At the same time the emphasis is made in favour of the economic security.

The division of the process of the economic development into the sustainable and the safe one is quite relative as in fact it is the common process where the leadership belongs to the process of a sustainable development [11]. The capability of the cities to conserve and to improve the parameters of the quality of life within the limits or above the limit of the security at the unstable situation of the external and the internal conditions (social, political, economic, technogenic, 
natural, climatic and others), which threaten the drop of the quality of life, determine the degree of the achievement of a sustainable development. The indices of the reduction of various violations of law due to a preventive maintenance are expected to become the criteria of the physical safety. The indices of the economic security are connected with the creation of a comfortable economic sphere via the development of the small business, sector of services, industrial services providing the employment of the population.

The cities of the XXI century are expected to have the opportunity and the capability of the transformation of the changes and the difficulties connected with them into the advantages by means of an active positive involvement into the events. The external and internal conditions of the existence are found in a constant dynamics and the goal consists in the knowledge to use them profitably and to move to another level of the development by means of the creation of real opportunities. Taking into account the mentioned specificity the concept is developed which corresponds to the notion of the "resilience". In the goals of the sustainable development set until year 2030 the notion "resilient" is used what corresponds to the Russian concept "sanguinity" but as we think a more precise notion for the creation of the strategy of the sustainable development is the idea of the "resilience".

The resilience means the conviction, understanding of the necessity of making changes and to remove difficulties. It is the awareness of the fact that the activity is always preferable than the passivity and in the end it is the opportunity to take into account the possibility of the risk when even working without the guarantees of a positive result.

The resilience of the cities is a way, an algorithm of action, assumption of the survival capability, opportunity to remain the winner in crisis situations. This characteristic allows reaching the results, efficiency, growth and development. The resilience includes the presence of such qualities like the awareness by the cities of their vulnerability and their real prospects. It can be presented in total as a sum of four components: obligation, monitoring, control, challenge, risk taking. The obligation provides a necessary level of development, a standard which is expected to achieve, an aspiration to do what was planned. The participation of the cities in the evolutionary changes taking place allows reaching the result (a positive one) from the realization of the plan.

Thus the territory capable of survival and the development in its concrete environment has the property of the sustainability. The notion of the sustainability of the cities like of any country is quite comprehensive. The classical interpretation implies the possibility of a dynamic system to hold the equilibrium, external and internal interference into its funcitoning.

The modern economic theory and practice does not have a common approach to the understanding of this economic category. In the basis of the notion of the sustainability of the development lies the theory of the maximal flow of the income the production of which is possible at the conservation of the total capital with the help of which this income is created. This theory implies the extraction of the maximal profit from the resource consumption.

The sustainability has a certain dual character as it can be seen as a regulated process from outside and at the same time a self regulating process. The sustainability is acceptable both in the stable condition and in the process of the changes by means of the emphasizing the process of the development (regression) of an object.

Taking into account the mentioned above the economic sustainability implies the maximal profit extraction so this can lead to the aggravation of the ecological situation and lead to the ecological threat [12].

The analysis of the economic literature showed that very often the authors identify the notions of the "sustainability" and of the "sustainable development" for instance when it is necessary to analyze the latter category. In our opinion the sustainable development is an economic category of a higher level what implies the triple bottom line concept of a sustainable ecological, social and economic development. In the economic literature the authors often connect and even replace the sustainability by such notions like safety, competiveness, resilience, sustainable development and so on. As it was mentioned above all these notions are interconnected but they vary both in a narrow and a broad understanding. The complex shown in the picture (CSSfRIP) presents the main conditions for a sustainable development of the cities and of the communities.

It is worth mentioning that the notions "sustainable development" and "competitiveness" have many common traits [13]. The analysis of the economic literature on the mentioned problems shows that today the problems of the competitiveness of the cities today are not handled within a common approach and an identical understanding. The methodology of the research of the competitiveness of the city, the conditions of its creation and the definitions are being developed and are far from the accomplishment [14].

For an objective assessment of the competitiveness of territories the classical analysis of the economy including a deep research of the development of the industries, education, healthcare, trade, science and the condition of the financial sphere (ways of creation and the sources of the budget incomes), ecological factors, conditions of the development of social districts of the city at the expense of the analysis of the condition of the human capital, labour input including the managerial potential and the management of the leading enterprises is indispensable. A detailed analysis of the situation in the industry and its main constituents: production capital, infrastructure, communal services, communal infrastructure, municipal improvement and resilience, competitive strength, weaknesses, opportunities, threats (SWOT analysis), potential growth points, potential spheres and directions, industries and sub industries, factors and the reserves of the creation of efficient enterprises of industrial economy, centers for innovative economy and venture business is important.

It is indispensable to suggest basic and crucial points of the modernization and the investment attractiveness of the city in 
respect to other large cities. This all provides the depth and the justification of the priority directions of the economic development of the city, an efficient solution of its main problems of the sustainable development and will allow increasing its competitiveness.

Despite the presence of various approaches to its classification the results obtained in the course of such an assessment play an important role for the development of a further strategy of the city development which uses this data. Herewith similar integral ratings and the methodologies of the ranking show that one territory is better than another one but they do allow seeing where the superiority lies and what the reasons of the lagging are. The common weak point of the studied methodologies consists in the absence of the opportunity of the assessment of the degree of the advantage or the extent of lagging behind of one territory from another.

The sixth condition of the successfulness of the realization of the measures in the provision of the sustainable development is potential or their perspectives. It is very often seen when such notions "strategy" and "prospect" are used as synonyms. The potential is the image of the anticipated events [15], future, expected "plans for the future" [16]. Judging from this position the prospect is a strategy. One of the versions of the notion "strategy" is "conception". This means that all the strategies present abstractions arising and living only in minds of the interested people. The peculiarity of the prospect is the necessity of its understanding and support among all or in the worst variant of the largest part of the society. In this case the prospect (perspectives) is harmonious with the ideas of the "collective intelligence": the conception of a sustainable development is realizable if the population of the city, local authorities and business community agrees with them. In this case it can be spoken about the fact that a sustainable development becomes a "world view" or a general understanding of the world structure.

\section{CONCLUSION}

The problem of the provision of a sustainable development of the cities and localities does not have neither racial nor language nor political boundaries.

The contemporary understanding and the dialectical development of the notion of the sustainable development in the context of the evolution of the city becomes more and more important at the stage of the implementation of the Federal Law "About the strategic planning in the Russian Federation" when all the Russian cities and regions work on the strategy development of their own territories.

The suggestions of the authors can be useful in the further development of a long term policy and additional measures at the realization of territorial strategies.

The life of the population in the conditions of the competitiveness, sustainability, safety, resilience, inclusiveness, perspectives (potential) of the territory, social and economic space can become the guarantee of a high standard and quality of life of city people.

\section{Acknowledgment}

The authors express profound gratitude to the Governor of the Volgograd region Andrey Ivanovich Bocharov for a high appreciation of their work of many years in theoretical and practical (on the example of the hero city of Volgograd) questions of the strategic development of the cities and we would like to thank him for the prize of the Volgograd region in the sphere of science and technology in the sector "Economics, management and finance".

The authors also would like to thank the Doctor of Economic Sciences, Professor Oleg Vasilievich Inshakov who made an invaluable contribution into the development of the theory and practice of the regional economy, into the support of the ideas of a sustainable development as a scientific consultant and a teacher.

The authors express profound gratitude to the interim of the Minister of the economy and territorial development of the Sverdlovsk region Tatyana V. Gladkova for a high assessment of the suggestions and methodologies of the authors at the development of the strategy of the social and economic development of the Sverdlovsk region (oblast) and of the city of Yekaterinburg.

The authors would like to thank the first vice mayor of Volgograd Vladlen Vladimirovich Kolesnikov for the support of the work in the promotion of the ideas of a sustainable development, preparation of the normative and legal base of Volgograd in the sphere of the strategic planning and the investment policy ensuring the image of the city as a "strategist city".

The authors would like to thank the colleagues and coworkers in the Administration of Volgograd and Volgograd universities.

\section{References}

[1] Bogomolova I. V., Bogomolov S. A. Krupnye goroda kak sotsial'noekonomicheskie sistemy: osobennosti, tendentsii i perspektivy ustoichivogo razvitiya [Large Cities as a Socio-economic Systems: Features, Trends and Prospects for Sustainable Development]. Sociology of the city [Sotsiologiya goroda], 2016, No. 3, pp. 16-27.

[2] Ponomareva L. V. Strategiya konkurentosposobnogo, ustoychivogo i bezopasnogo razvitiya ekonomiki regiona [Strategy for Competitive, Sustainable and Safe Development of the Economy of a Region]. Synopsis of the thesis of the Candidate of Economic Sciences. [Avtoreferat dissertatsii na soiskanie uchenoy stepeni kandidata ekonomicheskih nauk].Volgograd, 2007, 40p.

[3] Bogomolova I. V. Strategicheskoe planirovanie ustoychivogo razvitiya krupnyih gorodov indikativnyim metodom: opyit i perspektivyi modernizatsii [Strategic Planning of a Sustainable Development of Cities by means of an Indicative Method: Experience and Prospects of Modernization]. Volgograd: VolgGTU Publ, 2016, 251 p.

[4] Tseli v oblasti ustoychivogo razvitiya [The Goals of Sustainable Development]. Available at: http:// www.unic.ru/sites/default/files/oon_101_rus.indd_.pdf. Date of reference 29.02.2016

[5] Dmitriy Medvedev vyivel formulu inklyuzivnogo razvitiya ekonomiki Aziatsko-Tihookeanskogo regiona [Dmitry Medvedev Derived a Formula of an Inclusive Development of the Economy of the AsiaPacific Region]. Available at: http:// bujet.ru/article/126201.php. Date of reference 16.12.2015. 
[6] Ot legitimnyih vyiborov do effektivnoy rabotyi mestnyih organov samoupravleniya v sootvetstvii s ISO 18091 i ISO/TS 17582 [From the Legitimate Elections to the Efficient Operation of Local Authorities in Accordance with the ISO 18091 and ISO/TS 17582]. Available at: http:// intercert.com.ua/articles/posts/323-standarts-iso-18091-and-iso-ts17582-dlya-mestnih-i-izbiratelnih-organov-vlasti/. Date of reference 29.02.2016

[7] Dreyer O. K., Los W. A. «Ecology and Sustainable Development». Moscow : Izd-vo URAO Publ. 1997, 224 p.

[8] Inshakov O. V., Ponomareva L. V. Informatsionnyiy mehanizm i monitoring obespecheniya konkurentosposobnosti, ustoychivosti i bezopasnosti hozyaystvennoy sistemyi regiona [Information and Monitoring Mechanism of Ensurance the Competitiveness, Sustainability and Security of the Economic System of the Region]. Materials of scientific and practical conference. Volgograd, 2001, pp. 82-91.

[9] Ponomareva L. V. Mehanizm realizatsii strategii konkurentosposobnogo, ustoychivogo i bezopasnogo razvitiya regionalnoy ekonomiki [Mechanism of the implementation of the strategy of competitive, sustainable and secure Regional Economic Development]. Audit i finansovyiy analiz [Auditing and financial analysis], 2015, № 1, pp. 404-409

[10] Senchagov V. K. Ekonomicheskaya bezopasnost Rossii: Obschiy kurs [Economic security of Russia: General Course]. Moscow: Business Publ., 2005, 896 p.
[11] Korshunov L. A., Nikulina N. L.. Ekologicheskie i ekonomicheskie aspektyi ustoychivo- bezopasnogo razvitiya regiona [Environmental and Economic Aspects of a Sustainable and Safe Development of a Region]. Polzunovskiy almanah [Almanach of Polzunov], №3, 2011. pp. 4-8.

[12] Kremlev N. D. Ustoychivoe razvitie regiona v period nestabilnosti (na primere Kurganskoy oblasti) : monografiya [Sustainable Development of a Region in the Period of Instability (on the example of the Kurgan Region)]. Kurgan : Publishing house of Kurgan state University, 2015, $232 \mathrm{p}$.

[13] Bogomolova I. V., Slepchenko V. A. Osobennosti razvitiya i konkurentosposobnost postindustrialnyih gorodov. Sovremennaya ekonomika: problemyi i resheniya [Features of the Development and Competitiveness of Post-Industrial Cities in Modern Economics: Problems and Solutions]. Voronezh, Voronezh State University Publ., 2012, No. 8, pp. 8-23.

[14] Krupnyie goroda - resurs sotsialno-ekonomicheskogo razvitiya stran [Large Cities as a Resource for Socio-Economic Development]. International Forum "Megacity: XXI Century". 3 - 4 April 2008, p. 63.

[15] Perspektiva [Perspective]. Available at: http:// https://ru.wikipedia.org/ . Date of reference 29.02.2016.

[16] Perspektiva [Perspective]. Available at: http:// https://ru.wikipedia.org/ . Date of reference 29.02.2016. 